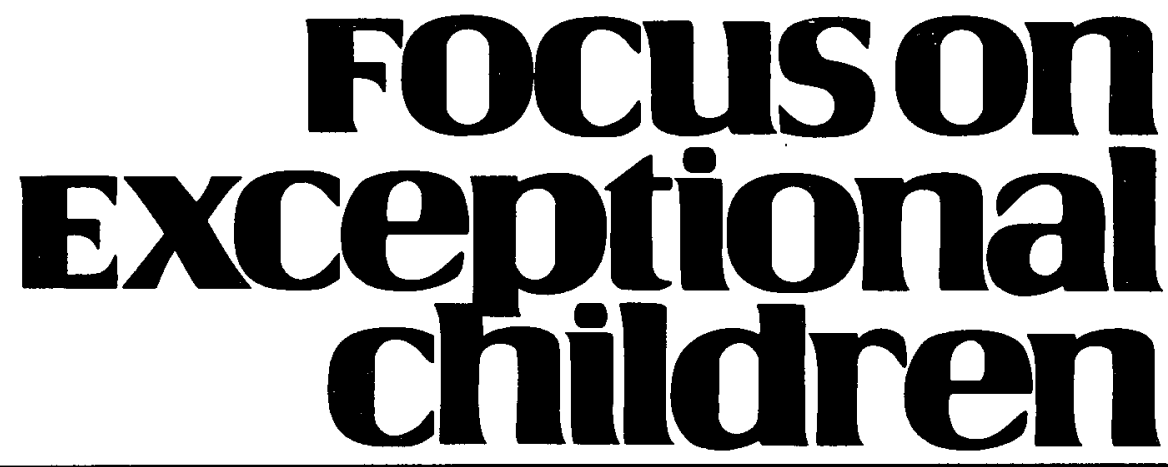

\title{
NCLBA and IDEA: Perspectives From the Field
}

\author{
by Kim Goodrich Ratcliffe and David T. Willard
}

Since the No Child Left Behind Act (NCLBA) became law in January 2002, media coverage has not been lacking - and for good reason. In an article in The Nation, Stephen Metcalf (2002) reported that "this year's reauthorization of the Elementary and Secondary Education Act is widely regarded as the most ambitious federal overhaul of public schools since the 1960s." Later in the year, a Philadelphia newspaper published a story describing NCLBA as causing upheaval in schools and stating, "A bold intrusion into local education policy, it has become the latest flash point for the Education Wars-from what makes a quality teacher to the best way to judge school and student progress" (Mezzacappa, Callas, \& Patrick, 2003).

NCLBA requires all children to meet state standards of proficiency. Nowhere does this seem more absurd than the requirement for subgroups of students with disabilities to meet the same standard as children without disabilities. Educators, parents, and students alike protested that to be labeled as a child with an educational disability, a child must meet both of the eligibility criteria: (a) the disability results in "significant adverse educational impact," and (b) the disability requires special education services. The criteria for "proficient" under NCLBA and the criteria to be diagnosed as a child with a disability under IDEA, the Individual with Disabilities Education Act, seem to be diametrically opposed: If a child meets the expectations under NCLBA, the child will no longer be eligible for special education services (Posny, 2004). Although most embraced the spirit of the law, many simultaneously rejected the "one-size-fits-all" mentality of the NCLBA mandates.

Five years have passed since reauthorization of the Elementary and Secondary Education Act (ESEA) that created NCLBA. This has allowed sufficient time for reaction from the schools and the U.S. Department of Education to the mandates for students with disabilities. In addition, in 2004 IDEA was reauthorized. Special educators were hoping that the confusion and conflict between the two federal laws would be clarified and resolved. Instead, tension remains between NCLBA and IDEA, further complicating the accountability issues for students with disabilities.

Kim Ratcliffe is the director of the Office of Special Education for the Missouri School Boards' Association (MSBA), and David Willard is an educational consultant for the Thomeczek Law Firm in St. Louis, Missouri. Drs. Ratcliffe and Willard are charter members of MSBA's 16-member Special Education Advocacy Council (SEAC). 
So what are school administrators thinking, and how are they responding to the mandates of NCLBA and IDEA? A trip across Missouri, the nation's heartland, provided an opportunity to take the pulse of public education in urban and rural areas, in public schools large and small. There is more than one story to be told. There is the story of professional analysis of the interplay between NCLBA and IDEA-special and general educators both taking a critical look at the purpose, the design, and the outcomes of the law for students with disabilities. There is the story of a new energy and excitement in public education, a resiliency that is driving educational reform-systems reform-in many progressive schools. This reform has at its heart the concept of all children truly perceived, owned, and educated by a unified system of education.

In the spirit of that reform, the scope of this article is limited, for the most part, to the impact of NCLBA on the education of students with disabilities. This is not because special education is an isolated and disconnected entity from the whole of the issues but, rather, because of space

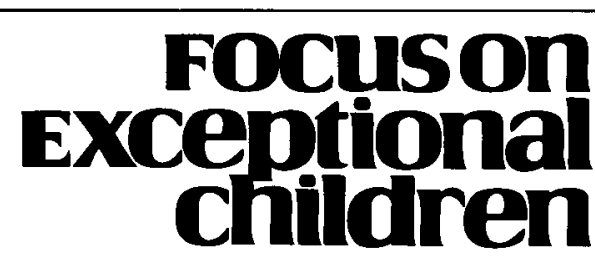

ISSN 0015-511X FOCUS ON EXCEPTIONAL CHILDREN (USPS 203-360) is published monthly except June, July, and August as a service to teachers, special educators, curriculum specialists, administrators, and those concerned with the special education of exceptional children. This publication is annotated and indexed by the ERIC Clearinghouse on Handicapped and Gifted Children for publication in the monthly Current Index to Journals in Education (CIJE) and the quarterly index, Exceptional Children Education Resources (ECER). The full text of Focus on Exceptional Children is also available in the electronic versions of the Education Index. It is also available in microfilm from Serials Acquisitions, National Archive Publishing Company, P.O. Box 998, Ann Arbor, MI 48106-0998. Subscription rates: individual, \$42 per year; institutions, $\$ 56$ per year. Copyright (c) 2006, Love Publishing Company. All rights reserved. Reproduction in whole or part without written permission is prohibited. Printed in the United States of America. Periodical postage is paid at Denver, Colorado. POSTMASTER: Send address changes to:

Love Publishing Company

Executive and Editorial Office P.O. Box 22353

Denver, Colorado 80222

Telephone (303) 221-7333

EDITORIAL BOARD

$$
\begin{array}{cc}
\text { Lisa Dieker } & \text { Paula Maccini } \\
\text { University of Central Florida } & \text { University of Maryland }
\end{array}
$$

Marleen Pugach

University of Wisconsin-Milwaukee

Susan T. Warhover Editor
Stanley F. Love

Publisher and focus. Finally, there is the story of a strong need for advocacy on the part of professional educators, professional education associations and organizations, and parents to articulate common-sense reforms to NCLBA that will both embrace the spirit of the law and result in improved outcomes for all children, including students with disabilities.

\section{THE INTERPLAY BETWEEN NCLBA AND IDEA}

The stated purpose of NCLBA reads in part:

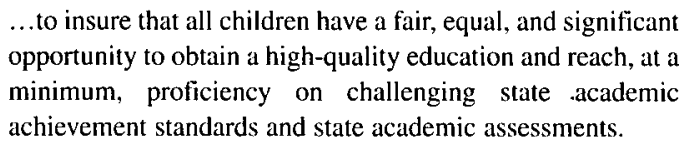

It is hard to find fault with the basic purpose of NCLBA, but as educators, we understand the difference between setting high expectations and holding schools accountable for all students' meeting the standards. This is a matter of goal versus standard. As special educators, we applaud and embrace including students with disabilities as full participants in NCLBA as well as maintaining high expectations for those students. As special education professionals, however, we identify a number of concerns regarding the singularity of the standard and the manner in which NCLBA is implemented.

\section{Assessment and Accountability of Students With Disabilities}

NCLBA and IDEA have a number of specific conflicts. According to the standard to which schools are accountable under IDEA, instruction is to be individualized and personalized to provide a free and appropriate public education known as FAPE. These keystones of IDEA-individualized and personalized - are absent in NCLBA. The absence leads to a significant conflict between the philosophies and requirements of the two acts.

John Heskett, Ed.D., former Missouri Assistant Commissioner for Special Education and past president of the National Association of State Directors of Special Education (NASDSE), offers this explanation:

IDEA establishes a clear preference that students with disabilities be educated with their peers who do not have disabilities, and, a clear expectation that students with disabilities have meaningful access to the general education curriculum. However, these concepts are established as refutable presumptions in the law. That is, if the Individualized Education Plan (IEP) committee determines that a student should receive a therapeutic placement where his/her educational and emotional needs can be addressed within a treatment program, the preference for placement with typically developing peers may be set aside for a more restrictive placement designed to meet the needs of the student. 
Or, if a student with a disability whose chronological peers are in the 8th grade has reading capabilities and computational skills assessed at the 4th grade level, IDEA expects that the IEP be designed to address the students' learning needs at his/her instructional level and to design the goal statements to reflect a level of progress that the IEP committee members believe is reasonable to be demonstrated within one year.

However, NCLB does not contain a similar "refutable presumption" with respect to assessment of students with disabilities. All students are expected to achieve proficiency as measured by the state assessment. So long as NCLB measures "success" as a fixed point of achievement on a scale, students with disabilities-as a subgroup-will not be considered "proficient." But policy makers have other options. They may create provisions in the law that allow students with disabilities to be "judged" based on the growth they demonstrate, rather than their relationship to a fixed point on a proficiency scale; and, to allow states to include social, emotional and functional data in the determination of proficiency.

This basic disrespect for the nature of disabilities and the decisions of the IEP team and disregard for the demonstration of abilities by children served under IDEA are what fuel the fire of frustration and result in a sense of hopelessness. According to Quality Counts 2004: "Count Me In: Special Education in an Era of Standards," by far the most contentious issue is how to test special education students and include those results in accountability systems ("Special Needs," 2004). Educators and parents alike find themselves on both sides of the issue. They applaud including students with disabilities in accountability measures and holding schools accountable for teaching students with disabilities to the highest standards possible while protesting the testing of such students against meaningless, unattainable standards or unfairly holding their test scores against schools or districts (Goldstein, 2004).

At the heart of the matter is IDEA's focus on the individual learner and the development and implementation of an IEP to ensure that instruction will be delivered at the child's level of academic and functional performance. But NCLBA assumes that all students can be instructed at grade level and mandates that all but those who have the most severe cognitive disabilities be assessed against grade-level achievement standards. The conflicting laws create a situation in which a child is instructed at a level consistent with his or her academic and functional performance but is tested at a level that may include content and concepts well beyond those in which the child has received instruction.

Litigation on high-stakes exit exams consistently attacks testing on content where instruction has not been given (Rene v. Reed, 2000). Several studies have indicated that $20 \%$ to $30 \%$ of children with disabilities should be exempted from grade-level testing (National Association of
State Directors of Special Education and National Education Association, 2004). Children, parents, and teachers in the field of special education find this fundamental conflict to be unfair, resulting in frustration on the students' parts and in disinclination on some parents' parts to include their students in the testing (Nagle \& Crawford, 2005).

NCLBA establishes an expectation that all children with disabilities will achieve one year of growth or multiple years of growth in one year to close the achievement gap. This expectation is not supported by any research or data developed since the inception of the federal special education mandate. Dr. Heskett points out that state data clearly demonstrate that students with disabilities have made significant progress in academic skills, and that this progress likely would not have occurred without the high expectations created by NCLBA.

\begin{abstract}
However, the majority of the movement has been from "basic" to "nearing proficiency" or from the bottom to the midlevel of state assessment systems. Even with concerted efforts, states' data do not demonstrate significant movement of students with disabilities from "nearing proficiency" to "proficient." The lack of data indicating such movement suggests the lack of achieving proficiency is related to intrinsic factors unique to the child rather than extrinsic factors related to the quality of education.
\end{abstract}

\section{Negative Consequences of a Flawed Law}

School administrators are additionally concerned by the backlash directed at students in low-performing subgroups and sanctions that can result from subgroups failing to make adequate yearly progress (AYP) in spite of potentially impressive academic and functional gains on the part of students. This concern gets at the heart of a larger matter. According to David Lineberry, Director of the Academy of Public School Governance, Missouri School Boards' Association: "The status accountability system under the NCLB measures academic movement at every organizational level except the one that matters the most-individual student progress in the classroom over the course of the instructional term."

Leaving no child behind and moving every child forward could result in two very different approaches to education. For one thing, the current system of accountability under NCLBA may encourage high-status schools to simply maintain a status quo and low-status schools to narrow the curriculum and concentrate only on the students whose academic achievement is below expectation. This could result in neglecting our brightest students or allowing them to simply tread water unless we set effective instruction and forward progress as the goal for all students. When student academic growth is combined with status, a much more complete picture of the quality of a school begins to emerge (Breisch, 2006). 


\section{Failing Accommodations}

A second source of conflict in the assessment of students with disabilities relates to accommodations that students use during assessments. IDEA requires that a student's IEP "include a statement of any individual appropriate accommodations that are necessary to measure the academic achievement and functional performance of the child on State and district-wide assessments" (IDEA Sec. 614(d)(1) (A)(i)(VI)(aa)). The purpose of such accommodations is to allow students with disabilities to demonstrate their knowledge on assessments without interference from their disabilities (Edgemon, Jablonski, \& Lloyd, 2006). NCLBA and the resulting state policies limit the use of accommodations, or, if the child with a disability uses certain accommodations, his or her performance is recorded as "level not determined."

Two of the four most commonly used accommodations for students at all grade levels-reading aloud and paraphrasing - are among those that, when utilized, result in the student's score counting against a district (Bielinski, Ysseldyke, Bolt, Friedebach, \& Friedebach, 2001; Koretz \& Hamilton, 2000). Thus, if the school does what IDEA requires, it is penalized by NCLBA. This requirement is unfair to children with disabilities and unfair to the school. In addition, it does not make sense in terms of meaningful or useful data.

This complex issue has even more layers. Some accommodations-such as reading aloud a test of reading comprehension or converting verbal or signed communication into standard written English for a test of written expressionmaterially alter the test. In essence, these accommodations change the nature of the test, in the first case from a reading comprehension test to a listening comprehension test, and in the second case from a test of written expression to one of oral/sign expression.

Setting aside some individualized needs driven by unique circumstances of a specific disability, these problems have solutions. Allowing the student to take a reading comprehension or written expression assessment at the student's instructional level instead of a grade-level assessment eliminates the need to have the assessment read aloud to the student or converted from oral or signed communication. Under a growth model of accountability, the resulting data provide accountability in terms of the student's progress in relation to instruction, so this model is a valid and useful measure.

A second solution is to allow the use of accommodations that do not invalidate the test constructs and have been proven to yield more accurate results for students with disabilities, while providing no notable advantage to students without disabilities. For example, under a new state policy in Texas, teachers can read aloud the proper nouns and question-and-answer choices on the reading comprehension test to third- through fifth-grade students with dyslexia, who also may take the test over 2 days instead of in one session. Reading aloud these portions of a reading comprehension test maintains assessment of reading-comprehension proficiency and provides no real advantage for nondisabled students. According to Jack Fletcher, a professor at the University of Houston who conducted field tests on the accommodation, the passing rates on the test increased from $9 \%$ to $41 \%$ for students with disabilities while the passing rate increased by only $2 \%$ for typical readers (Fletcher et al., 2006).

Diane Cordry Golden, Ph.D., Director of Missouri Assistive Technology, emphasized the importance of using a full range of assistive technologies and alternative formats to provide test accessibility and support independent written expression.
Students with vision disabilities can and should be expected to demonstrate proficiency on tests of reading comprehen- sion, so long as the test is provided in an accessible format, eliminating the need for such tests to be read aloud. Students with physical disabilities whose motor limitations prohibit them from using pencil and paper for writing can and should be expected to demonstrate proficiency on tests of written expression by using voice-recognition software or other computer adaptations (with advantages such as spell check- ers disabled), eliminating the need for human transcribers/ interpreters who could invalidate the results.

Dr. Golden further cautioned that test accommodations under NCLBA must be applied consistently for all students with disabilities:

\begin{abstract}
Too often policies disallow an accommodation, such as reading aloud for a test of reading comprehension, because it invalidates the test, yet [they] make an exception and allow that same accommodation for students with vision disabilities. Such disparate application of an accommodation cannot be justified and suggests inappropriately low expectations for students with certain types of disabilities.
\end{abstract}

\section{Finding Time for Transition Activities and Services}

A number of teachers and administrators of special education have expressed a concern with an outgrowth of the friction between the purposes of NCLBA and IDEA-the emphasis on academics to the detriment of other functional areas of importance to students with disabilities. Although it is defensible to expect all children to develop basic reading and math skills as a foundation for learning and functioning in society according to their abilities, for many students with disabilities, it is equally important to learn and practice life skills throughout $\mathrm{K}-12$.

IDEA requires that the area of transition from school to work be addressed annually in the students' IEPs, beginning no later than age 16. This requires assessment and related goals, activities, and services, as appropriate in the areas of 
training, education, employment, and independent living skills. According to special education administrators across Missouri, the need to concentrate heavily on accessing general education curriculum to maximize academic gains has resulted in less available time for teaching transition skills that may be critical to successful employment and adult living for students with disabilities.

This conflict between purposes of IDEA and NCLBA can be attributed in part to the definition of "proficient" as a static point on an academic assessment. As special educators, we have long recognized that for children with disabilities, proficiency involves more than academic performance and test scores. We find that a definition of proficiency based solely on reading and math scores fails to address skills and abilities that lead to proficiency as adults in the community and as participants in higher education or the workforce, not only for students with disabilities, but for other students as well. "The concept of educational accountability must be expanded to include competencies in social, emotional, and behavioral realms" (Faust, 2006).

A lack of proficiency in academics does not prohibit individuals with disabilities from being contributing members of our community. In defining "proficient, Congress must not make the mistake of substituting the fantasy of statistically impossible expectations-"the Lake Woebegone effect"for the bigotry of low expectations. Instead, to qualify as proficient, congress has to identify the threshold level of reading and math performance, as well as other skills and abilities.

\section{Highly Qualified Special Education Teachers}

It is reasonable to expect that all children be taught by highly qualified teachers. But the question of what constitutes a highly qualified special education teacher has elicited strong emotion and much debate. Some see the requirement for highly qualified teachers as the most problematic component in implementing NCLBA (Nagle \& Crawford, 2005). The NCLBA legislation does not address special education teachers specifically in relation to highly qualified teacher criteria. Nevertheless, the reauthorization of IDEA 2004 provided the direct link to NCLBA. In short, teachers of students with disabilities must complete the same basic coursework as required of all other teachers. In addition, they must complete specific coursework addressing special education competencies.

The Department of Education's narrow focus on core content areas for special education teacher certification is problematic because

1. it does not reflect an understanding of the actual job scope of many special education teachers,

2. it does not take into consideration the competencies needed to most directly impact the performance of students with disabilities, and

3 . it has the potential of further depleting an already critically short supply of qualified special education teachers.

In many small or rural school districts across the nation where only one or two special education teachers are employed districtwide, special educators may have the responsibility of instructing multiple core academic subjects in grades $\mathrm{K}-12$. Requiring special educators to demonstrate content expertise in each core subject they teach, as well as requiring certification in special education (which often requires multiple certifications to address the variety of disability conditions, severity levels, and grade levels), would force many special education teachers to obtain an unreasonable number of certifications. This predicament further compounds special education teacher shortages and makes it more difficult to ensure that children with disabilities receive specialized instruction when they need it. This is impractical and unnecessary when considering the unique discipline of special education.

The one fundamental question to ask and answer is: What is required to provide students with disabilities high-quality instruction that meets their unique learning needs resulting from their disabilities? One answer is that a teacher who meets the state's criteria could be certificated as a teacher of students with disabilities. This solution recognizes special educators as teachers in a distinct and unique discipline with its own certification and ensures that students with disabilities have teachers who are highly qualified to provide special education services.

The key to understanding the rationale behind this recommendation is found in the federal statute. IDEA requires that each child with a disability be educated with nondisabled children to the maximum extent appropriate. Each child with a disability shall be removed from the general education environment only when the nature or severity of the child's disability is such that education in general classes with the use of supplementary aids and services cannot be achieved satisfactorily. IDEA's least restrictive environment (LRE) principle is intended to ensure that a child with a disability is served in a setting where the child can be educated successfully.

Children with disabilities are served according to their individual needs at points along a continuum, one end of which represents an entire school day in the general education environment, and the other represents facilities apart from the mainstream of education. Although the number of students placed in particular environments continues to vary by disability category, according to a study by the federal Office of Special Education Programs (OSEP), 95.9\% of 
students with disabilities were served in general school buildings. The study further revealed that $87.1 \%$ of students with disabilities are educated outside of the general classroom for less than $21 \%$ of the school day (Office of Special Education and Rehabilitative Services, 2006). This means that the vast majority of students with disabilities have highly qualified teachers in the core content areas under NCLBA, because they receive their education in the general education classroom. Students who are educated apart from the general education classroom are educated in other environments because they cannot make satisfactory progress in the general education classroom. Although the reasons are student-specific, the required response is specially designed instruction.

According to the federal statute, the term specially designed instruction means

adapting, as appropriate, to the needs of an eligible child, the content, methodology, or delivery of instruction to address the unique needs of the child that result from the child's disability, and to ensure access of the child to the general curriculum, so that he or she can meet the education standards within the jurisdiction of the public agency that apply to all children.

Inherent in the special education process is the decision of where and how content skills are delivered. A child is served outside of the general classroom when specially designed instruction is the student's greatest need and is required for the student to make satisfactory progress. Therefore, a highly qualified special educator is one who can provide specialized instruction across the continuum of placements. Best practice dictates the need for close collaboration and frequent consultation between general educators and special educators, regardless of who has primary responsibility for delivering content instruction and regardless of environment. The other great risk in requiring special education teachers to meet general education content-area certification is the transfer of content-certificated teachers from special education to general education classrooms. This risk is particularly acute, given current shortages of general education teachers in subject areas such as mathematics and science.

It is undisputable that teachers of students with disabilities need a strong foundation in subject matter and teaching methodology in the core content areas. Teacher preparation programs for special education teachers across the nation typically require either the same or more rigorous standards than general teacher education programs in general content areas. Each state must be responsible for examining its teacher preparation programs to determine if the requirements constitute a solid base of understanding of general content areas. At the same time, states must ensure that they do not minimize special education requirements. By instituting excessive general education core content requirements, they would only dilute special education expertise for specific disabilities.

\section{NEW ENERGY DRIVING SYSTEMS REFORM}

Although NCLBA and IDEA mandates give rise to many concerns, daily frustrations, and difficulties in their implementation, we are beginning to see positive outcomes and improvement in the academic performance of students with disabilities as a direct or indirect result of these laws (Collins, 2005). More important, changes appear to be under way across the nation that eventually will address larger issues in special education. We have witnessed an undeniable momentum driving educational reform in individual districts across Missouri. Districts of varying wealth, size, and geographical location are driving reform, both as a result of NCLBA and in spite of NCLBA.

\section{Evolving the Unified Team, or the Wall Comes Tumbling Down}

For many special education teachers and administrators, it became apparent years ago that special education would not be "fixed" in isolation from general education. The requirements of NCLBA and IDEA have provided a new focus for leaders in general education, special education, and educational associations on systemic reform, educational practices, resources, and educational services (White, 2005). This has benefited special education and general education alike. Today, new forces seem to be aligned. Increased diversity among students, pressures from the federal government under NCLBA, and creativity and ingenuity by staffs are molding a more unified educational system. This new synergism supports diversity within the student population and provides real opportunities for academic success for all students. "Leaders recognize the wall must come down between general and special education to meet the higher standards for student learning and to reduce educational fragmentation" (White, 2005). As special educators, we must seize the moment and capitalize on opportunities to effect change throughout the educational system that will address critical issues in special education and result in improved outcomes for all children.

Visiting schools and speaking with educators, we have uncovered tangible evidence of new policies and systemic change in procedures and practices that have improved outcomes for students. Educators have spent 5 years being frustrated by unrealistic mandates and an unattainable standard under NCLBA. Now they are redirecting their efforts toward changes that will result in effective instruction for all students. Monitoring the progress of all students, intervening at the earliest possible time when a student is not keeping pace (as opposed to when the student has a record of failure), and using data to determine effective strategies and methods of instruction to be used with individual children have resulted in many districts' reporting academic growth for all students 
and a decrease in special education referrals. The focus has shifted from referring struggling students to the "program down the hall" to talking about all students in a building as a diverse but unified whole.

Separating special education issues from general education issues is difficult because they are inexorably linked. According to Steven Beldin, Director of Pupil Services, North Kansas City District:

It was a lot of factors coming together-it was more of an evolution that was given renewed energy under NCLB. We wanted to see growth in our students with disabilities, to focus less on accommodations and more on student achievement.

The process began in North Kansas City District in the late 1980s and early 1990s, with teacher support teams as an outgrowth of inclusion. In the 1990s the district became concerned with the steady increase in the special education incidence rate. Mr. Beldin explained:

The over-identification of students with special needs dovetailed with the need to give regular educators more resources and supports to educate an increasingly diverse group of students.

Today, early identification of students struggling with the curriculum results in a team approach to consider and apply different instructional strategies. Data are closely monitored for effectiveness of interventions, and strategies are changed as necessary to ensure students' progress. North Kansas City District has joined with other districts across the state to provide leadership in applying the concept of response to intervention to struggling students. According to Mr. Beldin:

The goal is to raise the achievement level for all students.... While special effort is being made to close the gap between the performance levels of students who lag behind and established achievement standards, we want all children to achieve as much as they can and go as far as they can.

\section{General Education Administrators Influencing Change}

General education administrators have become active in implementing these changes. General education administrators are being held accountable for all students in their building, including students with disabilities. Administrators are communicating to their staffs the need to intervene at the earliest possible point when a student is struggling and the need for instruction to be scientifically based, datadriven, and monitored regularly. "We are a high-performing district overall," explained Thurma DeLoach, Ph.D., Director of Instructional Services, Kirkwood School District. She continued:

NCLB was the reason we started looking at subgroupslooking at data and using that data to drive instructional decisions. NCLB was the impetus for problem solving and intervention. It generated a new emphasis on general education taking the responsibility for support and intervention before considering special education. We realized that we could not wait for kids to slip in a major way, i.e. to fail, if we were going to raise our achievement scores and meet the benchmarks for disaggregated groups. Special education used to be our primary support system; we waited until students were significantly behind to be eligible for special education. It really was a backwards approach. Schools in our district were ready for the change. They knew it was a better way for kids but did not have the reason to look beyond special education before NCLB.

Administrators are analyzing the performance data of all students, including those with disabilities. This practice alone has resulted in heightened expectations for performance outcomes of students with disabilities, resulting in an analysis of instructional practices with implications for professional development and teacher accountability. In short, principals are holding the same expectations for special educators that they traditionally have reserved for only general educators. According to Dr. DeLoach:

\begin{abstract}
We didn't look at the collective progress of our students in special education before NCLB, and we didn't consider general education to be accountable for them in any way. That has changed significantly, and it is eye opening to see how well our students with disabilities can achieve.
\end{abstract}

\section{Staff Development to Promote Focus and Develop Competencies}

Many successful schools carefully plan professional development of all certificated staff as a unified whole. School administrators extol the benefits of all teachers' knowing the goals, how they are going to get there, and how they will be measured. Carol Garman, Ed.D., Principal of Eugene Field Elementary School in Columbia, Missouri (75.7\% free and reduced lunch and $68.1 \%$ minority representation), explained that she started with an intensive year of teacher preparation and training. A past administrator of special education, she strongly advocates looking at each child as an individual regardless of any special programs that might support their child: "It is not programs but people that make things work."

Field Elementary introduced a schoolwide disciplinary system called Positive Behavior Support and a similar threetiered approach to reading using the University of Oregon model. "This is putting the tools in the hands of the teachers," Dr. Garman stated. She went on to say:

One of the most heartening things we have found is that when you take the focus off of behavior and focus on academics, the children rise to the expectation; when they meet the academic expectations, we don't have the acting out behaviors. We constantly talk to the children about growth 
as readers. We communicate daily that everyone is capable of reading; we expect them to be readers and writers and they are not disappointing us.

\section{Changing Roles and Responsibilities}

The role of general and special education teachers is also evolving. For some time, general and special education teachers have shared the general classroom under a variety of arrangements for the purpose of teaching and supporting students with disabilities included in general classrooms. Today a new understanding - an ownershipis resulting in the general educator accountability for the progress of students with disabilities in the general education class. According to Dr. DeLoach, the general educator is viewed as the point person for instruction, with a heavy emphasis on collaboration and support from the problemsolving team.

Lynda Shrader, Executive Director of Elementary Education in Raytown School District, shares a similar story:

Regular education'teachers today are more accountable for students with disabilities. They are seeing students with disabilities as learners and talking intensely about instruction. We are focusing on strategies which are embedded within the curriculum rather than environmental accommodations. Regular teachers are realizing they have the power to move children with disabilities along and to generalize the instruction to benefit so many others.

Some of the techniques reserved for special educators in the past, such as using individual ongoing assessment of students' learning and changing instructional strategies to ensure that each student is progressing, are being utilized by general educators to benefit other students in class as well. Janet Earl, Director of Special Services, Joplin School District related:

\begin{abstract}
As NCLB magnified the issues of achievement, it was clear that we were going to have to find a way to make it work for all kids. We had to figure out ways to do that together, which included regular educators applying some of the same strategies to students with diverse learning needs in their classrooms as special educators were using.
\end{abstract}

Many districts began to realize the benefits in tracking individual student data as they allocated resources and articulated professional development plans that for the first time included training special and general educators together. According to Beth Emmendorfer, Ed.D., Director of Special Services, Jackson School District:

NCLB was the impetus for the purchase of a data system that allows us to track individual student progress from year to year. This has resulted in individual learning plans for all students and systemic approaches of improving student achievement instead of each building having a separate school improvement plan. With our students with disabilities not making AYP, it made sense for special educators to be a part of school improvement teams and to participate in professional development.

Other districts reported additional ways of "breaking down the system," including requiring special educators to attend grade-level and departmental faculty meetings.

Another change has been to direct resources, as early and intensely as possible, to both prevention and intervention measures. This has resulted in general and special educators teaming up to utilize their respective training and apply their unique competencies to benefit children. Early intervention is the name of the game today, according to Dr. DeLoach:

\begin{abstract}
We have a new mentality that has resulted in a huge reduction in special education referrals. Regular education teachers believe and have been given the training and support to understand how they can be a part of the solution for a struggling child. They feel empowered to make a difference. In addition, under the IDEA 2004, special education support can be flexible and can be used as a part of early intervention strategies before students are identified with disabilities. We have found this to be an important part of both prevention and quality early interventions.
\end{abstract}

School administrators are no longer caught up in the frustration of an unattainable standard and are directing their efforts toward the effective instruction of all students. Ms. Shrader reports they are beginning to feel that they have control:

\begin{abstract}
We are breaking down paradigms; we are seeing that we can make changes to help children achieve the impossible. As we began to individually assess students in reading and writing on an ongoing basis, we got to know each student as a learner. We no longer think in terms of NCLB; the forward progress of children has taken on a life of its own.
\end{abstract}

\section{COMMON-SENSE REFORM OF NCLBA}

Undeniably, the NCLBA, either directly or indirectly, has been the catalyst for some good things happening in America's schools. NCLBA also has been responsible, directly or indirectly, for negative practices that, if continued, could undermine the world-class education that America's children receive-an education that ensures democracy for future generations and America's top seat in world leadership and the global economy.

And so must a third story be told - a story of advocacy for common-sense reforms to the NCLBA that will both embrace the spirit of the law and result in improved outcomes for all children, including students with disabilities. This is not an easy assignment for educators. Historically, educators have operated in a reactionary mode, so engrossed in the process of educating children that we have had little time or energy to be proactive on behalf of children and our profession. That simply must change. As the 
professional group charged with the awesome task of educating every child to the best of his or her ability regardless of compounding circumstances, we must be problem solvers, and we must make our solutions known to policy makers.

\section{Aligning Reforms With the Spirit of the Law}

In October 2001, the Missouri School Boards' Association brought together a group of special education professionals from across Missouri and formed an advocacy council to address special education issues at the state and federal levels. This group, the Special Education Advocacy Council (SEAC), meets bimonthly for regularly scheduled meetings and more frequently when necessary to engage in study, review, research, and advocacy related to implementation of special education within the context of a unified education system.

As Congress prepares to consider the reauthorization of NCLBA, SEAC reviewed the effectiveness of the Act's implementation in meeting the 12 purposes that Congress identified in the original Act, to direct attention to components of the Act worthy of strengthening and to identify those areas requiring common-sense reform. As we review implementation of the NCLBA in Missouri, the Special Education Advocacy Council (SEAC) of the Missouri School Boards' Association provides the following observations and suggestions.

\section{SEC. 1001. STATEMENT OF PURPOSE.}

The purpose of this title is to ensure that all children have a fair, equal, and significant opportunity to obtain a high-quality education and reach, at a minimum, proficiency on challenging State academic achievement standards and state academic assessments.

This purpose can be accomplished by...

COMMENT: SEAC strongly supports that all children have a fair, equal, and significant opportunity to obtain a highquality education. As special education professionals, we applaud and embrace the inclusion of students with disabilities as full participants in NCLBA. We also identify a number of concerns regarding the manner in which NCLBA is implemented. Our concerns call to mind a quotation attributed to a former U.S. Supreme Court justice, Felix Frankfurter: "There is nothing so unequal as the equal treatment of unequals."

Under the Individuals with Disabilities Education Act (IDEA), instruction is to be individualized and personalized to meet the standard of providing a free and appropriate public education (FAPE) to each child with a disability. The absence of these two keystones of the IDEA-individualized and personalized instruction-leads to significant conflicts between the philosophies and approaches of the two acts. The primary conflict is best seen in IDEA's emphasis on instruction at the child's level of performance and NCLBA's assessment at the child's grade level. Two additional areas of conflict between the two statutes are that

1. NCLBA significantly weakens, if not totally removes, the discretion of the IEP team as decision maker for children with disabilities in regard to assessments and accommodations for assessments; and

2. NCLBA establishes an expectation that all children with disabilities will achieve more than one year of growth or multiple years of growth in one year to close the achievement gap. Such an expectation is not supported by any research or data developed since the inception of IDEA.

\footnotetext{
(1) Ensuring that high-quality academic assessments, accountability systems, teacher preparation and training, curriculum, and instructional materials are aligned with challenging State academic standards so that students, teachers, parents, and administrators can measure progress against common expectations for student academic achievement...
}

COMMENT: The SEAC strongly endorses the application of the same high expectations for children with disabilities, as applied to all children. But standards are not instruction, and assessment is not teaching. The Act, as currently implemented, focuses on testing rather than high-quality instruction. NCLBA has to place greater emphasis on growth rather than measurement if academic performance for all students is to improve.

We are alarmed by some of the unintended consequences of NCLBA. These consequences include movements to narrow the curriculum by narrowing the concentration on reading and mathematics at the expense of fine arts, the humanities, physical education, and recess. For children who enter the school system already behind, exposure to the fine arts-including music, literature, and graphic arts-is prerequisite and foundational for future learning. Narrowing the curriculum further limits the opportunities for instructional progress for those who start behind. We find it ironic that since the passage of NCLBA and the unanticipated reductions in physical education and recess, there has been a significant increase in awareness of the lack of physical fitness in America's youth.

As special education professionals who have seen the impact of the lack of availability of high-quality special education teachers for many years prior to the passage of NCLBA, we strongly support the call for highly qualified teachers. We endorse a two-pronged criterion for all teachers to be considered highly qualified under the NCLBA: (a) a baccalaureate degree, and (b) state certification. 
We also note limited support at best in the Act for efforts to address the shortage of highly qualified teachers. The reauthorization of NCLBA has to make a greater commitment to teacher preparation and outline a package of incentives to address recruitment and retention of highly qualified teachers in public education. This would include recruitment and retention of teachers in areas of critical shortages in the teaching profession, including mathematics, the sciences, and other areas, in addition to special education.

\begin{abstract}
(2) Meeting the educational needs of low-achieving children in our Nation's highest-poverty schools, limited English proficient children, migratory children, children with disabilities, Indian children, neglected or delinquent children, and young children in need of reading assistance...
\end{abstract}

COMMENT: As special educators who have been working with children with disabilities and other low-achieving children for nearly 40 years, we recognize the value of focused early interventions. A program such as Reading First exemplifies the high-quality instruction that must be expanded in the reauthorized Act. The expansion must address other instructional areas (specifically, mathematics and science) and an earlier overall start of the interventions in all areas. Research is addressing the benefit of early interventions, such as the Perry Preschool Project (Schweinhart, 2006) and the longitudinal studies of the impact of Head Start, which clearly support the benefits of early intervention with the targeted populations (Love et al., 2002/2004).

More emphasis and support must be directed to early intervention services through programs such as Parents as First Teachers, IDEA Part C Early Interventions, Early Childhood Education, and other preschool programs. Scientifically based research indicates that early intervention programs have a positive impact on children's growth and development (Puma et al., 2005). We simply must put a significant amount of money and energy behind the efforts that are proven to have the greatest payoffs for children at the earliest possible juncture in their learning.

We also note scientifically based research regarding achievement that recognizes factors beyond the school's control that impact school performance. ESEA historically has targeted all types of children-low-achieving children in our nation's highest-poverty schools, limited-English-proficient children, migratory children, children with disabilities, American Indian children, neglected or delinquent children, and young children in need of reading assistance-through special programs to enhance achievement for nearly 40 years in recognition of their special instructional needs. NCLBA seems to have forgotten its own important history and the basis for its initial implementation.

(3) Closing the achievement gap between high- and low-performing children, especially the achievement gaps between minority and non-minority students, and between disadvantaged children and their more advantaged peers...

COMMENT: We at SEAC find this purpose of the act to be problematic. Both philosophically and educationally, we find that this purpose establishes undesirable and false goals and unrealistic expectations. The purpose should be to raise the performance of all children, not simply to close the gap. As special educators, we know that all children can learn, but we also know that not all children learn the same things at the same rate.

The belief that school experiences can close a gap predating the child's entry into school has no scientific basis. Gaps are created because of the lack of quality preschool experiences, lack of adequate nutrition, lack of adequate health care, lack of adequate housing, and lack of other supports that are prerequisites of academic achievement and school success. (Berliner, 2005). Nothing in the Act addresses these critical foundations for adequate learning.

Closing the gap implies that some children must accelerate their learning and others must slow their rate of learning, allowing those who are behind to catch up. Statistically, this approach seems to be a regression toward the mean. We find such a strategy unacceptable. Closing the gap also sets an expectation that those who historically have achieved the least must now achieve the most. More than 30 years of experience with IDEA has produced no scientifically based research to support this possibility.

Rather than closing the gap, the goal should be to set high expectations for all children. Holding back the top while accelerating the bottom lowers expectations for all. As Charles Murray (2006) noted, "It [NCLBA] holds good students hostage to the performance of the least talented, at a time when the economic future of the country depends more than ever on the performance of the most talented." Some critics of NCLBA have described this unintended consequence as "the rush to the bottom." The purpose of NCLBA should be to rush to the top. Reauthorization should change the expectancy so the goal is not to close the gap but, instead, to raise the performance of all children.

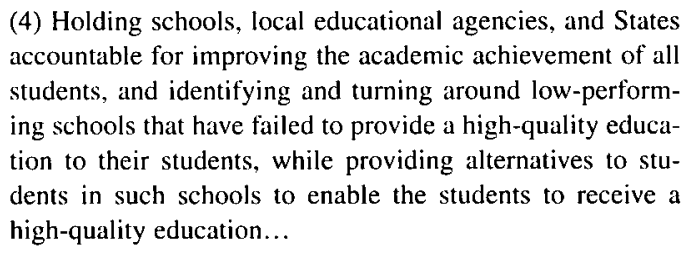

(4) Holding schools, local educational agencies, and States accountable for improving the academic achievement of all students, and identifying and turning around low-performing schools that have failed to provide a high-quality education to their students, while providing alternatives to students in such schools to enable the students to receive a high-quality education...

COMMENT: All schools must be accountable. Schools that fail to provide high-quality instruction must be improved. NCLBA's accountability model, however, has produced unintended consequences that hinder school improvement and have to be addressed in the reauthorization. First, the 
current system of determining adequate yearly progress (AYP) overidentifies schools as underperforming. When multiple subgroups of children must meet arbitrary levels of performance, there are multiple ways to fail to make adequate yearly progress but only one way to attain AYP. Large and culturally diverse schools must meet 40 or more targets. Failing to meet one can lead to designation as "needs improvement." Thus a percentage of 97.5 becomes a failing grade under NCLBA $(100-\{1 / 40\}=97.5 \%)$.

While the Department of Education recognizes the potential value of different approaches to determining AYP, as evidenced through the interest in growth models, only two states have been allowed the opportunity to begin implementing such models. We believe that the reauthorization should allow all states, school districts, and schools to implement AYP models based on individual student growth, growth models, value-added models, and/or any other model that demonstrates improved student performance.

One of the benefits of modifying the AYP model is to reduce the overidentification of schools as needing improvement. By identifying fewer schools as needing improvement, resources can be concentrated on the schools that are most in need of improvement.

There are additional needs to look at school improvement, choice, supplemental services, and restructuring. Once a school is identified as "needs improvement," the time frame for school improvement is too short. Schools are complex social institutions, and turnaround typically takes 3 to 5 years. One of the unintended consequences of overidentifying schools as needing improvement is to limit the parents' options involving school choice and supplemental services. In many large and diverse school systems, many more children have qualified for both school choice and supplemental service options than realistically could be provided. By modifying the AYP model to identify fewer schools as needing improvement, the options of choice and supplemental services can be targeted to students who are most in need and most likely to benefit from such options.

We strongly recommend that the reauthorization consider offering additional services to parents. One option that is noticeably absent is to extend the school year by providing summer programs with reading and mathematics instruction to subgroups of children who fail to make adequate yearly progress.

Further, we strongly urge that the reauthorization change the order of the options of school choice and supplemental services. Supplemental services should be the first option for parents when their children's schools continue to show need for improvement. The Gallup poll (Rose \& Gallup, 2005) has consistently shown that parents prefer that their child receive educational services in the community school. Reauthorization also should limit supplemental services and school choice to only those students in subgroups failing to make AYP, thereby directing services to those who need them most. Finally, supplemental services should be provided only by teachers who meet the state's highly qualified teacher requirements.

(5) Distributing and targeting resources sufficiently to make a difference to local educational agencies and schools where needs are greatest...

COMMENT: NCLBA as authorized and NCLBA as implemented differ significantly in funding. Actual funding levels have not met the authorized levels, and implementation of the Act has additional funding problems. For example, the Act authorizes state grants to schools identified as needing improvement, but some states have not been able to make such funds available. The set-asides called for in the Act have led to a reduction of Title I funds available to individual schools. Funds needed for choice transportation have reduced funds available for instruction. Funds used for supplemental services reduce the funds available to implement the Title I programs. The unintended consequence is less funding for the targeted populations of children. The Act undermines the very focused funding necessary to turn a school around.

(6) Improving and strengthening accountability, teaching, and learning by using State assessment systems designed to ensure that students are meeting challenging State academic achievement and content standards and increasing achievement overall, but especially for the disadvantaged..

COMMENT: We agree that challenging academic standards are needed for all. We appreciate the availability of the National Assessment of Education Progress (NAEP) as a benchmark to determine if individual state standards are rigorous enough. We are concerned, however, that emphasis on all children being proficient will have an unintended consequence of lowering expectations, as described above, in a rush to the bottom. While $100 \%$ proficiency is a laudable goal, it is an unrealistic expectation.

Implementation of growth models, value-added models, and other models directed to improving the academic performance of all children should lead to a differentiation between the goal and the standard under NCLBA. SEAC recommends that the goal remain " $100 \%$ of children to be proficient" and the standard redefined as " $100 \%$ of students either demonstrate proficiency or demonstrate growth toward proficiency."

There also must be improved alignment between accommodations allowed on state assessment systems and accommodations used by students with disabilities in the learning process; and accommodation policies must be applied consistently for all students with disabilities. As long as an accommodation does not invalidate the underly- 
ing construct being tested, students with disabilities who routinely use assistive technology or other accommodations for instruction should be able to use those same technologies and accommodations in any assessment process. By the same token, if an accommodation does invalidate the test, it should be disallowed for students with all types of disabilities, not allowed for some and disallowed for others.

(7) Providing greater decision making authority and flexibility to schools and teachers in exchange for greater responsibility for student performance..

COMMENT: Unfortunately, we on SEAC have seen little evidence of flexibility in implementation of NCLBA. To date, NCLBA has been a top-down model with the Department of Education directing state departments of education, which in turn direct school districts, which direct schools, which direct teachers. Input and direction from those most responsible for implementing the Act have been limited at best. Our review of the literature on school improvement shows such a model to be the least likely approach to produce genuine change.

Implementation of NCLBA must be restructured to reflect the State's responsibility for public education as laid out in the Constitution. The role of the federal government in public education should be to support the states' efforts, not to direct the states. The Department of Education must allow states more flexibility in implementing and monitoring the Act. The role of the federal government should be to promote research, provide benchmarks to help states assess the rigor of their systems, such as those provided through NAEP, and provide incentives to support the states' efforts.

(8) Providing children an enriched and accelerated educational program, including the use of school-wide programs or additional services that increase the amount and quality of instructional time...

COMMENT: Implementation of NCLBA seems to have had the opposite effect. Evidence noted previously has shown that, instead of an enriched educational program, NCLBA has pressured some schools to implement a narrower curriculum.

Implementation of NCLBA has produced other unintended consequences that limit opportunities for some children. For example, there are numerous anecdotal reports of "bubble children" and "NCLB triage" (Booher-Jennings, 2006). In an attempt to meet the AYP, schools are concentrating their resources on children who are most likely to be boosted into the proficient range while limiting instruction and resources to those who most likely will not achieve proficiency.
Proficient students may become the next "at-risk" group in our nation. Public schools in the United States operate within a limited resource model, not a cost-plus model. In approaching $100 \%$ proficiency, more and more resources will have to be directed to the lowest-performing children at the expense of all other children. The effect will be less quality instruction for those at or above proficiency. Gradelevel proficiency cannot be the preferred standard for all students. Where a student begins instruction each year must be part of the equation for students above and below gradelevel proficiency. Otherwise, underachievement will become yet another form of leaving a child behind. Schools should be geared toward improving the performance of individual students, every day in every possible way, without regard to their demographic identity. The NCLBA AYP model must be changed so every child will count.

(9) Promoting school-wide reform and ensuring the access of children to effective, scientifically based instructional strategies and challenging academic content...

COMMENT: Anecdotal information would indicate that systemic reform is taking place in schools that have progressive leadership. It seems to be happening out of frustration with a flawed federal mandate and in spite of the pressure to simply survive the Act and engage in practices that are counterproductive to effective instruction for all students.

By and large, educators have not been trained to be consumers of educational research. Much remains to be done in partnership with institutions of higher education to prepare educators for analyzing and applying educational research to instruction of children both collectively and individually, as learning needs dictate. The reauthorization must place greater emphasis on federally sponsored research and on disseminating scientifically based instructional practices.

(10) Significantly elevating the quality of instruction by providing staff in participating schools with substantial opportunities for professional development...

COMMENT: While SEAC recognizes the value of continuous, focused, and high-quality staff development in school improvement, the resources provided through the Act have been used primarily to fund testing and compliance with the Act. This has left limited resources for staff development and other school-improvement activities that are at the very heart of improved outcomes for all students. We highly support fully funding ESEA and using a portion of the additional funding to target high-quality instruction through substantial opportunities for professional development.

(11) Coordinating services under all parts of this title with each other, with other educational services, and, to the extent feasible, with other agencies providing services to youth, children, and families... 
COMMENT: As noted above, SEAC has great concerns about the very real conflicts between the philosophy and implementation of NCLBA and IDEA.

(12) Affording parents substantial and meaningful opportunities to participate in the education of their children.

COMMENT: As special education professionals, SEAC members know the value of educational practices that help forge the partnership between parents and professionals and the added value of parental participation in decision making. We strongly support NCLBA's attempts to build and strengthen this partnership for all children. We commend both reporting to parents through report cards and providing information concerning highly qualified teachers. We strongly support parent and other stakeholder involvement in the school-improvement process and in decisions related to supplemental services and school choice. We are concerned, however, about the diminished role of parents of children with disabilities as a result of losing the IEP team, including the parent, as the mechanism to determine appropriate assessment for the child and to make other individualized and personalized educational decisions concerning the child.

\section{Moving Forward With Positive Action}

These are exciting and challenging times in public education. For the first time since IDEA was passed, there is the real possibility of a unified system of education that will place primary importance on meeting the needs of all students and that, by the nature of the design, will address several critical issues in special education. We must step up to the plate and ensure that these special education issues are properly identified and resolved through deliberate plans containing measurable outcomes.

We must work to strengthen those parts of the NCLBA that benefit all children and apply common-sense reform to those parts of the Act that fail to advance the goal of improved achievement for all children. Educators at all levels must work for common-sense reform of NCLBA. We must not simply wait for our congressional leaders to address the reauthorization without benefit of our first-hand experience and educational expertise. We have a moral and ethical responsibility to get involved. We must work for continuous improvement in public schools to ensure that all children have a fair, equal, and significant opportunity to obtain a high-quality education. It is the right journey for our children, our profession, and the future of our country.

\section{REFERENCES}

Berliner, D. C. (2005). Our impoverished view of educational reform, Teacher's College Record, August 2, 2005, Retrieved August 28, 2005, from http://www.shutupandteach.org/impoverished.pdf
Bielinski, J., Ysseldyke, J., Bolt, S., Friedebach, M., \& Friedebach, J. (2001). Prevalence of accommodations for students with disabilities participating in a statewide testing program. Assessment for Effective Intervention, 26(2), 21-28.

Booher-Jennings, J. (2006). Rationing education in an era of accountability, Phi Delta Kappan International, Retrieved July 13, 2006, from http://www.pdkintl.org/kappan/k_v87/k0606boo.htm

Breisch, B. (2006). School success: status and growth. In Case, 47(5), $1-2$.

Collins, E. (2005). Leaders as models for collaboration: Meeting the new challenges and creating opportunities with NCLB and IDEA. Journal of Special Education Leadership, 18(2), 41-42.

Edgemon, E. A., Jablonski, B. R., \& Lloyd, J. W. (2006). Large scale assessments: A teacher's guide to making decisions about accommodations. TEACHING Exceptional Children, 38(3), 6-11.

Faust, J. (2006). Adequate yearly progress: Bane or opportunity? In CASE, 47(5), 3-4.

Fletcher, J. M., Francis, D. J., Boudousquie, A., Copeland, K., Young, V., Kalinowski, S., and Vaughn, S. (2006). "Effects of accommodations on high-stakes testing for students with reading disabilities". Exceptional Children, 72(2), 136-152.

Goldstein, L. (2004). Long-Awaited special education testing rules issued, Education Week, January 7, 2004, vol. 23, p. 27.

Koretz, D., \& Hamilton, L. (2000). Assessment of students with disabilities in Kentucky: Inclusion, student performance, and validity. Educational Evaluation and Policy Analysis, 22(3), 255-272.

Love, J. M., Kisker, E. E., Ross, C. M., Schochet, P. Z., Brooks-Gunn, J., Paulsell, D., Boller, K., Constantine, J., Vogel, C., Fuligni, A.S., \& Brady-Smith, C. (2002/2004). Making a difference in the lives of infants and toddlers and their families: The impacts of Early Head Start: Vol I. Final technical report. Princeton, N.J.: Mathematica Policy Research Inc. Retrieved May 23, 2006, from http:// www.masthematicampr.com/publications/pdfs/ehsfinalvol I.pdf

Metcalf, S. (2002) "Reading Between the Lines," The Nation, 28 January 2002 , www.thenation.com/doc.mhtml $\% 3 \mathrm{Fi}=20020128 \& \mathrm{~S}=$ metcalf.

Mezzacappa, D., Callas, T., and Patrick, K. (2003) Battles ahead over No Child Left Behind, Philadelphia Inquirer, 11-18-03, http:// www.philly.com/mId/philly/7288593.htm

Murray, C. (2006). Acid Tests: No Child Left Behind is beyond uninformative. It is deceptive. Wall Street Journal. Retrieved July 25, 2006, from http://www.opinionjournal.com/forms/printThis.html ?id $=110008701$

Nagle, K. M., \& Crawford, J. (2005). Perspectives on NCLBA from special education directors in urban school districts. Journal of Special Education Leadership, 18(2), 8-14.

National Association of State Directors of Special Education and National Education Association. (2004, Nov.). IDEA \& NCLB: The Intersection of Access and Outcomes. Washington, DC. NASDSE/NEA Joint Publication.

Office of Special Education and Rehabilitative Services United States Department of Education, 2006, Twenty-Sixth Annual Report to Congress on the Implementation of the Individuals with Disabilities Education Act, 2004, Volume 1, p. 30.

Posny, A. (2004). Clash of the titans: No Child Left Behind and students with disabilities. Paper presented at Center on Education Policy's forum on ideas to improve the NCLB accountability provisions for students with disabilities and English language learners on September 14, Washington, D.C. Retrieved on June 4, 2005 from http:// www.cepdc.org/pubs/Forum 14September2004/PochowskiPaper.pdf 
Puma, M., Bell, S., Cook, R., Heid, C., Lopez, M., Zill, N., Shapiro, G., Broene, P., Mekos, D., Rohacek, M., Quinn, L., Adams, G., Friedman, J., \& Berstein, H. (2005). Head Start impact study: First year findings. Washington, DC: U.S. Department of Health and Human Services, Administration for Children and Families. Retrieved May 23, 2006, from http://www.acf.hhs.gov/programs/opre/hs/impact-study/reprots/first-yr-finds/first-yr-finds.pdf Rene v. Reed, 32 IDELR 196 (IN Sup Ct 2000).

Rose, L. C., and Gallup, A. M. (2005). 37th annual Phi Delta Kappa/Gallup poll of the public's attitudes toward the public schools, Phi Delta Kappa International, Retrieved on July 25, 2006, from http://www.pdkintl.org/kappan/k0509pol.htm
Schweinhart, L. J. (2006). Lifetime effects: The High/Scope Perry Preschool Study through age 40: Summary, conclusions, and frequently asked questions. Accessed on July 25, 2006, from http://www.high scope.org/Research/PerryProject/PerryAge40_SumWeb.pdf

Special Needs, Common Goals. (2004, January 8) Education Week, p. 3. Retrieved January 8, 2004, from http://www.edweek.org/sreports/qc04/article.cfm?slug=17exec.h23

White, D. (2005). Superintendent's commentary: The challenge for general education administrators in supporting students with disabilities under No Child Left Behind and the Individuals with Disabilities Education Improvement Act. Journal of Special Education Leadership, 18(2), 43-44. 
Copyright of Focus on Exceptional Children is the property of Love Publishing $\mathrm{Co}$. and its content may not be copied or emailed to multiple sites or posted to a listserv without the copyright holder's express written permission. However, users may print, download, or email articles for individual use. 